Article

\title{
Assessment of Geogenic Contaminants in Water Co-Produced with Coal Seam Gas Extraction in Queensland, Australia: Implications for Human Health Risk
}

William Stearman ${ }^{1, *}$, Mauricio Taulis ${ }^{1}$, James Smith ${ }^{1}$ and Maree Corkeron ${ }^{1,2}$

1 School of Earth, Environmental and Biological Sciences, Queensland University of Technology, R Block, 2 George St, Brisbane, QLD 4001, Australia; E-Mails: mauricio.taulis@qut.edu.au (M.T.); jj.smith@qut.edu.au (J.S.); maree.corkeron@qut.edu.au (M.C.)

2 School of Earth and Environmental Sciences, James Cook University, Townsville, QLD 4810, Australia

* Author to whom correspondence should be addressed; E-Mail: w.stearman@qut.edu.au; Tel.: +61-422-366-036; Fax: +61-731-381-535.

Received: 14 July 2014; in revised form: 8 August 2014 / Accepted: 13 August 2014 /

Published: 5 September 2014

\begin{abstract}
Organic compounds in Australian coal seam gas produced water (CSG water) are poorly understood despite their environmental contamination potential. In this study, the presence of some organic substances is identified from government-held CSG water-quality data from the Bowen and Surat Basins, Queensland. These records revealed the presence of polycyclic aromatic hydrocarbons (PAHs) in $27 \%$ of samples of CSG water from the Walloon Coal Measures at concentrations $<1 \mu \mathrm{g} / \mathrm{L}$, and it is likely these compounds leached from in situ coals. PAHs identified from wells include naphthalene, phenanthrene, chrysene and dibenz[a,h]anthracene. In addition, the likelihood of coal-derived organic compounds leaching to groundwater is assessed by undertaking toxicity leaching experiments using coal rank and water chemistry as variables. These tests suggest higher molecular weight PAHs (including benzo[a]pyrene) leach from higher rank coals, whereas lower molecular weight PAHs leach at greater concentrations from lower rank coal. Some of the identified organic compounds have carcinogenic or health risk potential, but they are unlikely to be acutely toxic at the observed concentrations which are almost negligible (largely due to the hydrophobicity of such compounds). Hence, this study will be useful to practitioners assessing CSG water related environmental and health risk.
\end{abstract}


Keywords: coalbed methane; coal seam gas; coalbed natural gas; co-produced water; polycyclic aromatic hydrocarbons

\section{Introduction}

The commercial production of CSG (coal seam gas, also known as "coalbed methane", "coal seam methane" or "coalbed natural gas") in the Bowen and Surat Basins, Queensland (QLD) has emerged as an important unconventional natural gas supply and cleaner energy alternative than conventional fossil fuels. CSG production requires the withdrawal of groundwater from coal seams and associated strata to depressurize the coal, allowing natural gas (mainly methane) held in coal micropores to desorb and flow through the coal's fractures to a production well for extraction. The groundwater withdrawn from coal measures is referred to here as "CSG water", but is also commonly known as "produced water", "formation water" or "associated water". In 2009-2010, an estimated 17 gigalitres (GL) of CSG water was extracted from Queensland gas fields supplying the domestic gas market [1]. As CSG production increases to supply international liquefied natural gas (LNG) markets, annual volumes of extracted CSG water are estimated to increase to over ten times the 2009/2010 production rate (e.g., to about $200 \mathrm{GL} /$ year by 2030) [2].

CSG water is distinct from "flowback water", which is the fluid recovered from a gas production well soon after water, sand and other chemical additives have been injected during hydraulic fracturing ("fracking"). Where hydraulic fracturing occurs, the "flowback water" is extracted and its volume is usually $110 \%-150 \%$ the volume of the injected fracturing fluid considering the contribution of formation water. Any produced water after the $110 \%-150 \%$ volume recovery of flowback water should be considered CSG water [3]. Furthermore, distinctions should be made between coal seam gas and other unconventional gas resources such as shale gas and underground coal gasification (UCG), to avoid incorrectly applying environmental management strategies which are specific to other types of technology in the gas industry.

The withdrawal and disposal of CSG water is perhaps the most important environmental management issue associated with CSG production, due to the large volumes of water being extracted, its specific water quality and its natural variations [4,5]. The often highly sodic and alkaline chemical composition of CSG water in Queensland presents potential risks to surface soils, shallow aquifers and watersheds [6,7]. Under the Environmental Protection Act 1994, CSG water is defined as a waste product of gas extraction. However, the Queensland government (Department of Environment and Heritage Protection) strongly encourages the beneficial reuse of CSG water for the environment, landholder and rural communities as best management practice [8].

\subsection{Co-Produced Water and Human Health}

Whereas attention has been given to assessing environmental risk related to CSG water, little scientific consideration is given to human health impacts. Community groups opposed to CSG development often make unqualified public statements insinuating human toxicity risk from CSG production water (e.g., [9]). Additionally, several studies [10-13] hypothesize the link between coal 
derived organic compounds in rural groundwater and kidney disease (Balkan Endemic Nephropathy, BEN). However, very few studies directly assess CSG water composition and its potential for adverse human health impacts. Closing this knowledge gap would best constrain the risk (if any) to landholders and communities in QLD that access water supply from coal associated aquifers (e.g., Walloon Coal Measures), communities receiving potable supply from treated CSG water [14] and stakeholders who may be exposed directly or indirectly to CSG water [15].

Most studies of CSG water quality focus on its inorganic composition, including salinity, high sodicity and trace metal occurrence [16-25]. For example, the vast majority of QLD CSG waters contain elevated $\mathrm{Na}^{+}, \mathrm{HCO}_{3}{ }^{-}$and sometimes $\mathrm{Cl}^{-}$as the dominant ions, have fresh to brackish salinity (200-10,000 mg/L) and neutral to basic $\mathrm{pH}(\mathrm{pH} 7-9)[6,26]$. However, the concentrations of the major ions in CSG water are often site or basin specific, reflecting localized lithological and hydrological controls.

Less literature exists regarding the organic composition of CSG water. Coal is a complex, organic sedimentary rock that contains many compounds that are known, or have the potential to be, hazardous to human health. These include polycyclic aromatic hydrocarbons (PAHs), heterocyclic compounds, phenolics, biphenyls and aromatic amines. Since CSG water is groundwater in contact with coal, there is potential for leaching of trace levels of organic compounds from those coals. Among the more important factors that influence the inventory of potentially mobile organic compounds in coal are maceral type, coal rank, coal age and the nature of microbial degradation acting on those coals [27]. While there is a theoretical likelihood for potentially toxic organic compounds in CSG water, studies testing and discussing this are scarce (see [27-29]).

In Queensland, publicly available baseline and monitoring data regarding organic substances in CSG water is mainly limited to company environmental impact assessments and consultant reports [30,31]. These data are often limited to the common aromatic compound classes-PAHs, phenolics and BTEXs (benzene, toluene, ethylbenzene and xylene)—which are all usually reported below detection limits from well and holding pond samples.

The organic composition of CSG water from the Powder River Basin (WY, USA) was described as part of a larger study on the potential health effects of coal derived organics [28]. At ultra-trace detection levels $(<1 \mu \mathrm{g} / \mathrm{L})$, the most commonly observed group of organic compounds from the Powder River Basin CSG waters were the PAHs (with total PAH concentrations ranging up to $23 \mu \mathrm{g} / \mathrm{L}$ ), along with trace levels of phenols, biphenyls, heterocyclic compounds and aromatic amines. Similar compounds have been reported (at trace levels) in CSG water from other US gas plays such as the Black Warrior Basin, Tongue River Basin, Williston Basin and Illinois Basin [32]. In addition to the semi-volatile aromatics, BTEX compounds have been detected in CSG water from wells targeting the San Juan and Raton basins in the United States, with benzene concentrations ranging from below detection limits, up to $500 \mu \mathrm{g} / \mathrm{L}$ [26]. BTEX compounds have also been reported from eight CSG exploration wells in the Surat Basin, but little specific information is publicly available [27].

In assessing human health risk, presence of chemical compounds alone does not automatically equate to higher risk. Concentrations, bioavailability and exposure pathways are equally important variables impacting risk but identification of potential toxins in source material (CSG water) are the first requirement in risk assessment. The high density of CSG production wells in the Surat and Bowen Basins of southern Queensland provides an excellent opportunity to characterize the organic composition of CSG water. This study determines the concentration and types of some likely coal-derived 
organic compounds in CSG water from production wells targeting Jurassic Walloon Coal Measures of the Surat Basin and the Permian Bandanna Formation of the Bowen Basin from a 2010 dataset. In addition, in order to test for leachable organic compounds from coal and therefore potential contaminants in CSG water, we undertook a series of leachate experiments on fresh coal samples of differing rank. Preliminary experimental results are presented to characterize the release of aromatic compounds from coal to water. These findings are pertinent to future human health and environmental risk assessment as the first step in clarifying the presence of potential toxins.

\subsection{Study Areas}

The Permian to Triassic Bowen Basin is the northern extension of the Bowen-Gunnedah-Sydney Basin system of eastern Australia. To the west the Bowen Basin is linked to the Galilee and Cooper Basins and to the south, it is overlain by the Surat Basin (Figure 1). CSG fields currently in production in Queensland include both Bowen and Surat Basin coal seams (Bandanna Formation and Walloon Coal Measures, respectively).

Figure 1. Coal seam gas (CSG) water study areas and localities for coal samples used in leaching experiments. The red boxes mark high production areas where CSG water is extracted from the Bandanna Formation (Bowen Basin) and Walloon Coal Measures (Surat Basin). The desktop CSG water quality data was taken from these areas.

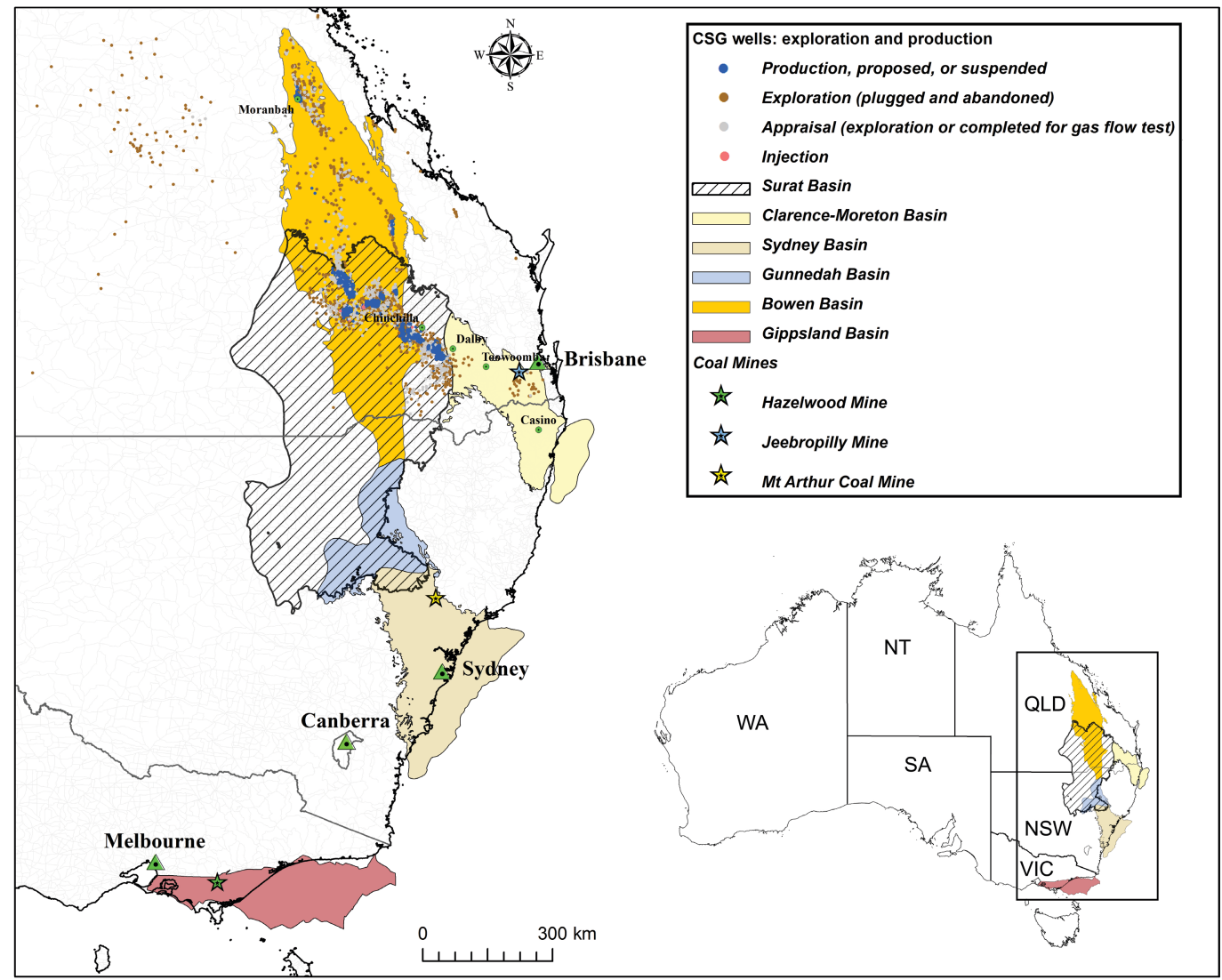




\subsubsection{Bandanna Formation, Bowen Basin}

The late Permian Bandanna Formation consists of siltstone, lithic sandstone, carbonaceous shale and coal. The depositional setting of the Bandanna Formation is interpreted as a large fluvio-deltaic system infilling a lake, or a land-locked sea, which is recorded in the underlying Black Alley Shale [33]. The seams targeted for gas production in the study area consist of high vitrinite coals (up to 70\%) with a mean maximum vitrinite reflectance ( $\mathrm{Rv}, \max )$ of approximately $0.9 \%$ [34]. The Bandanna coals of the study area are high volatile-A (HvA) bituminous to medium volatile (Mv) bituminous in rank and in general, they occur in relatively thicker and more laterally extensive seams than that of the Walloon Coal Measures of the eastern Surat Basin [35,36].

\subsubsection{Walloon Coal Measures, Eastern Surat Basin}

The Walloon Coal Measures consists of lithic sandstones, siltstones and claystones with thin coal seams [37,38]. The depositional setting of the Walloon Coal Measures was an alluvial plain, traversed by meandering streams. Coal measures occurred mainly as swampy overbank and flood plain deposits. Coal seams thicknesses are variable and are often split as a result of from constant stream channel switching $[37,39,40]$. Coal seams targeted for CSG production are the Juandah and Taroom coal measures which are separated by the Tangalooma Sandstone and unconformably overlain by the Springbok Sandstone. The coals of the study area are sub-bituminous to high volatile-C (HvC) bituminous with an Rv, max between $0.35 \%$ and $0.65 \%$ [36,38]. CSG well depths of the study area are 451-825 $\mathrm{m}$ and rank increases with depth $[36,38]$.

\section{Methods}

\subsection{CSG Water Organic Analyses}

Desktop analysis of government-held water quality data from gas producing wells was conducted to characterise some organic compounds in CSG water. The data were originally collected by the CSG industry and supplied to QLD Government as a regulatory requirement. It is assumed that all relevant quality assurance and control checks were conducted by the samplers and analysts that produced these datasets, although chain of custody data were not available.

The dataset included organic analyses from 58 production wells targeting the Permian Bandanna Formation from 2009 to 2010 and 47 production wells from the Walloon Coal Measures from 2010. Additional organic analyses were from the holding pond of the Walloon Coal Measures production area from 2010. Analytes are common organic compound classes of environmental importance (e.g., PAHs, phenolics and BTEXs).

\subsection{Leaching Experiments}

A series of leaching experiments was undertaken on a range of coals of differing rank in order to determine the potential leachability of semi-volatile PAHs and phenolic compounds. The patterns of aromatic compounds in coal change with increasing coal maturity [41-43] and therefore the water leachable aromatic fraction may also change. The experiments aimed to assess the difference in 
mobility of PAHs and phenolics from coals of different rank (lignite to bituminous) when leached using different water types (acidic to basic). The toxicity characteristic leaching procedure (TCLP) is a standard method (United States Environmental Protection Agency, USEPA, Washington, DC, USA) to determine the mobility of both organic and inorganic analytes present in liquid and solid materials (USEPA Method No. 1311) and was here adapted and applied to solid coal samples. Table 1 shows the leaching conditions used in this study. In addition to TCLPs performed with the standard acetic acid fluid, adapted TCLP experiments were also performed with deionized water and a synthetic CSG water solution. Coal samples were leached in triplicate with deionized water including a batch of tests conducted with powdered coal samples $(<400 \mu \mathrm{m})$. Coal samples were leached in duplicate with the synthetic CSG water (Table 1).

Table 1. Leaching experiments and conditions. All experiments were performed at room temperature $\left(25^{\circ} \mathrm{C}\right)$ for $18.5 \mathrm{~h}$.

\begin{tabular}{ccc}
\hline Sample\# & Coal & Leachant \\
\hline A-LIG-1 & Lignite & TCLP Extraction fluid \# 1 \\
A-SUB-1 & HvA-bituminous & TCLP Extraction fluid \# 1 \\
A-BIT-1 & Mv-bituminous & TCLP Extraction fluid \# 1 \\
N-LIG-1 & Lignite & Deionised water \\
N-SUB-1 & HvA-bituminous & Deionised water \\
N-BIT-1 & Mv-bituminous & Deionised water \\
B-LIG-1 & Lignite & Synthetic CSG \\
B-SUB-1 & HvA-bituminous & Synthetic CSG \\
B-BIT-1 & Mv-bituminous & Synthetic CSG \\
N-LIG-2 & Lignite & Deionised water \\
N-SUB-2 & HvA-bituminous & Deionised water \\
N-BIT-2 & Mv-bituminous & Deionised water \\
B-LIG-2 & Lignite & Synthetic CSG \\
B-SUB-2 & HvA-bituminous & Synthetic CSG \\
B-BIT-2 & Mv-bituminous & Synthetic CSG \\
P-LIG-3 & Lignite $*$ & Deionised water \\
P-SUB-3 & HvA-bituminous * & Deionised water \\
P-BIT-3 & Mv-bituminous * & Deionised water \\
NB-1 & n/a & Deionised water \\
BB-1 & n/a & Synthetic CSG \\
\hline
\end{tabular}

Notes: $\mathrm{n} / \mathrm{a}=$ control samples, ${ }^{*}$ powdered $(<400 \mu \mathrm{m})$ coal samples.

The deionized water leachant for all leach experiments was Milli-Q ultra-filtered water. The synthesized CSG water used was mixed according to the observed ionic character of production waters. Most often, the dominant ions in QLD CSG water are sodium $\left(\mathrm{Na}^{+}\right)$, bicarbonate $\left(\mathrm{HCO}_{3}^{-}\right)$and chloride $\left(\mathrm{Cl}^{-}\right)$. To achieve this $\mathrm{Na}-\mathrm{HCO}_{3}-\mathrm{Cl}$ chemical type, analytical grade sodium chloride $(\mathrm{NaCl})$ and sodium bicarbonate $\left(\mathrm{NaHCO}_{3}\right)$ were dissolved in Milli-Q water. The final $\mathrm{pH}$ of the synthetic CSG water used in each extraction varied from 8.6 to 8.9 with an average total dissolved solids (TDS) concentration of $1350 \mathrm{mg} / \mathrm{L}$. 
All glassware used in the leaching experiments was cleaned carefully to minimize contamination. Prior to use in leach experiments or filtrations of leachates: glassware and Teflon lined caps were hot soaked in detergent overnight, scrubbed and rinsed successively in tap water, deionised water and acetone. If any excessive contamination was observed on the equipment, it was soaked overnight in $20 \%$ nitric acid prior to the regular rinsing process. Glassware and glass fiber filters were baked in an oven overnight at $150{ }^{\circ} \mathrm{C}$ before use in experiments and sample collection the next day. Glassware used to collect filtered samples was pre-contaminated with a small volume of filtrate and that volume was discarded before additional filtering took place. Controls were treated in the same way as samples during the experiments.

Extraction and Analysis

All TCLP leachates were vacuum filtered through $0.6-0.8 \mu \mathrm{m}$ glass fiber filters with glass and porcelain filtration apparatus and collected in amber glass bottles with Teflon-lined caps. In brief, all filtered TCLP samples were stored at $<4{ }^{\circ} \mathrm{C}$ for sample preservation prior to liquid/liquid extraction with dichloromethane for analysis. Analysis was conducted using a Finnigan SSq 710 gas chromatography/mass spectrometer operating in full scan mode according to Queensland Health and Forensic Scientific Services (QHFSS) SOP No. 15639 for PAHs and phenols.

\subsection{Coal Samples}

All coal samples used in the leach experiments were taken from open-cut coal operations in eastern Australia. The coal samples and their properties are shown in Table 2. The surface portion of each coal sample was chipped away to maximize fresh exposed coal.

Table 2. Coal samples used for leaching experiments and basic properties. Figure 1 shows the locations of basins and coal mines relevant to this study.

\begin{tabular}{cccccc}
\hline Sample & Locality & Age & $\begin{array}{c}\text { Carbon \% } \\
(\mathbf{d . a . f} *)\end{array}$ & $\begin{array}{c}\text { Vitrinite Reflectance } \\
(\mathbf{R v}, \mathbf{M a x})\end{array}$ & Rank \\
\hline LIG & Gippsland Basin, Victoria & Middle Miocene & 66 & $0.3 \%$ & Lignite B \\
\hline \multirow{2}{*}{$S U B$} & Moreton Basin, Queensland & Middle Jurassic & 80 & $0.57 \%$ & $\begin{array}{r}\text { High volatile } \\
\text { bituminous A }\end{array}$ \\
\hline \multirow{2}{*}{$B I T$} & $\begin{array}{c}\text { Sydney-Gunnedah Basin, } \\
\text { New South Wales }\end{array}$ & Early Permian & 85 & $0.67 \%$ & $\begin{array}{r}\text { Medium volatile } \\
\text { bituminous }\end{array}$ \\
\hline
\end{tabular}

Note: * Dry, ash free.

\section{CSG Water Results}

CSG waters from production wells targeting the Bandanna Formation contain no PAH or BTEX compounds above detection limits. The minimum detection limit for PAHs in the Bandanna Formation analyses was $1 \mu \mathrm{g} / \mathrm{L}$, except for benzo[a]pyrene $(0.5 \mu \mathrm{g} / \mathrm{L})$. BTEX compounds were analyzed at 1 to $2 \mu \mathrm{g} / \mathrm{L}$ detection limits. These detection limits are equal to those applied to organic analyses in publicly available reports which also reported nil detections for aromatic compounds e.g., [31]. Currently, there is no standard set for analytical detection levels of aromatic compounds from coal seam gas water. 
Detection limits used in the Walloon Coal Measures CSG water samples (circa $0.01 \mu \mathrm{g} / \mathrm{L}$ ) were two orders of magnitude lower than the Bandanna Formation analysis. The concentrations and detection limits for select organic compounds from CSG waters of the Walloon Coal Measures are shown in Table 3. 13 of the 47 wells analyzed (27\%) had ultra-trace concentrations of PAH compounds. All 47 wells had nil detections for phenolic compounds and the 14 wells analyzed for BTEX compounds also reported nil detections.

The most commonly detected PAHs were naphthalene and phenanthrene which were both detected in seven sampled wells. The maximum naphthalene and phenanthrene concentrations from a single well were $0.046 \mu \mathrm{g} / \mathrm{L}$ and $0.02 \mu \mathrm{g} / \mathrm{L}$, respectively. Of all detected PAHs, naphthalene was detected at the highest concentration, followed by benzo[b+k]fluoranthene $(0.033 \mu \mathrm{g} / \mathrm{L})$. The benzo[b+k]fluoranthene analyte is the total concentration of the benzo[b]fluoranthene and benzo[k]fluoranthene compounds and individual concentrations of each cannot be ascertained. Of the 47 sampled wells, only five produced CSG water with more than one individual PAH compound and the maximum total PAH concentration reported from any single well was $0.083 \mu \mathrm{g} / \mathrm{L}$.

Table 3. Concentrations of polycyclic aromatic hydrocarbons (PAHs) from Walloon Coal Measures' CSG waters, as sampled from production wells. Only detected PAHs are shown. $\mathrm{BDL}=$ below detection limit.

\begin{tabular}{cccc}
\hline PAHs & $\begin{array}{c}\text { Detection Limit } \\
(\boldsymbol{\mu g} / \mathbf{L})\end{array}$ & Range $(\boldsymbol{\mu g} / \mathbf{L})$ & $\begin{array}{c}\text { \% of Wells with } \\
\text { Detections }\end{array}$ \\
\hline Naphthalene & 0.01 & BDL-0.046 & 23 \\
Phenanthrene & 0.01 & BDL-0.046 & 20 \\
Pyrene & 0.01 & BDL-0.01 & 2 \\
Chrysene & 0.01 & BDL-0.016 & 2 \\
Benzo[b+k]fluoranthene & 0.01 & BDL-0.033 & 9 \\
Dibenz[a,h]anthracene & 0.01 & BDL-0.014 & 9 \\
\hline
\end{tabular}

\subsection{CSG Water Holding Pond}

The CSG water holding pond of the Walloon production area was sampled six times over a one month period in 2010. In this dataset, naphthalene and phenol were the only detected compounds at $0.06 \mu \mathrm{g} / \mathrm{L}$ and $0.3 \mu \mathrm{g} / \mathrm{L}$, respectively. Both analytes were only detected once during the sampling program. None of the higher molecular weight PAHs were detected in the holding pond.

\subsection{Leaching Experiment Results}

No PAHs or phenolic compounds were reported in the leachates of the standard TCLPs performed with the acetic acid solution from any coal rank. The minimum detection levels for that group of TCLPs were $0.5-1 \mu \mathrm{g} / \mathrm{L}$ for PAHs and 1-2 $\mu \mathrm{g} / \mathrm{L}$ for phenolics. These results suggest that even during a high energy agitation in an acid fluid, these aromatic compounds will not leach at considerable concentrations. Analytical detection levels for the deionized and synthetic CSG water solutions were lowered appropriately to assess whether these hydrophobic substances will leach at ultra-trace $(0.01 \mu \mathrm{g} / \mathrm{L})$ concentrations. 
PAHs were present in the deionized water (Table 4) and synthetic CSG water (Table 5) leachates. Individual PAH compounds leached from coal samples included: naphthalene, phenanthrene, fluoranthene, pyrene, chrysene, benz[a]anthracene, benzo[b+k]fluoranthene and benzo[a]pyrene. Naphthalene was detected at the highest concentrations $(0.42$ to $0.67 \mu \mathrm{g} / \mathrm{L})$ and only leached from lignite. The only other PAH compound to leach from lignite samples was phenanthrene (at a concentration of $0.01 \mu \mathrm{g} / \mathrm{L}$ ) and only in one synthetic CSG water leach. In four of the five tests performed with lignite, phenol leached at average concentrations of $0.3 \mu \mathrm{g} / \mathrm{L}$.

Table 4. Concentration ranges of selected organics from toxicity characteristic leaching procedure (TCLP) experiments performed with deionized water. $\mathrm{BDL}=$ below detection limit.

\begin{tabular}{|c|c|c|c|c|}
\hline \multirow{2}{*}{$\begin{array}{c}\text { Polycyclic aromatic } \\
\text { hydrocarbons }\end{array}$} & \multirow{2}{*}{$\begin{array}{c}\text { Detection Limit } \\
(\mu \mathrm{g} / \mathrm{L})\end{array}$} & \multicolumn{3}{|c|}{ Coal Rank } \\
\hline & & Lignite & HvA-Bituminous & Mv-Bituminous \\
\hline Naphthalene & 0.01 & $0.43-0.67$ & $\mathrm{BDL}$ & $\mathrm{BDL}$ \\
\hline Acenaphthylene & 0.01 & $\mathrm{BDL}$ & BDL & $\mathrm{BDL}$ \\
\hline Acenaphthene & 0.01 & BDL & BDL & BDL \\
\hline Fluorene & 0.01 & BDL & BDL & BDL \\
\hline Phenanthrene & 0.01 & BDL & BDL & BDL-0.01 \\
\hline Anthracene & 0.01 & $\mathrm{BDL}$ & BDL & $\mathrm{BDL}$ \\
\hline Fluoranthene & 0.01 & BDL & BDL-0.03 & BDL-0.03 \\
\hline Pyrene & 0.01 & BDL & BDL-0.02 & BDL-0.05 \\
\hline Benz[a]anthracene & 0.01 & BDL & $\mathrm{BDL}$ & BDL-0.02 \\
\hline Chrysene & 0.01 & BDL & BDL & BDL-0.01 \\
\hline Benzo $[b+k]$ fluoranthene & 0.01 & BDL & BDL & BDL-0.01 \\
\hline Benzo[a]pyrene & 0.01 & BDL & BDL & BDL-0.01 \\
\hline Indeno[1,2,3-cd]pyrene & 0.01 & BDL & BDL & BDL \\
\hline Dibenz[a,h]anthracene & 0.01 & BDL & BDL & $\mathrm{BDL}$ \\
\hline Benzo[ghi]perylene & 0.01 & BDL & BDL & $\mathrm{BDL}$ \\
\hline Phenolics & $\begin{array}{c}\text { Detection Limit } \\
(\mu \mathrm{g} / \mathrm{L})\end{array}$ & Lignite & HvA-Bituminous & Mv-Bituminous \\
\hline Phenol & 0.25 & BDL-0.32 & BDL & BDL \\
\hline 2-Chlorophenol & 0.25 & BDL & BDL & $\mathrm{BDL}$ \\
\hline 2-Methylphenol & 0.25 & BDL & BDL & BDL \\
\hline 4-Methylphenol & 0.25 & BDL & BDL & $\mathrm{BDL}$ \\
\hline 2-Nitrophenol & 0.25 & BDL & BDL & $\mathrm{BDL}$ \\
\hline 2,4-Dimethylphenol & 0.25 & BDL & BDL & BDL \\
\hline 2,4-Dichlorophenol & 0.25 & BDL & BDL & BDL \\
\hline 2,6-Dichlorophenol & 0.25 & BDL & BDL & $\mathrm{BDL}$ \\
\hline 4-Chloro-3-methylphenol & 0.25 & BDL & BDL & $\mathrm{BDL}$ \\
\hline 2,4,6-Trichlorophenol & 0.25 & BDL & BDL & $\mathrm{BDL}$ \\
\hline 2,4,5-Trichlorophenol & 0.25 & BDL & BDL & BDL \\
\hline 2,4-Dinitrophenol & 2.5 & BDL & BDL & BDL \\
\hline 4-Nitrophenol & 1 & BDL & BDL & $\mathrm{BDL}$ \\
\hline 2,3,4,6-Tetrachlorophenol & 0.3 & BDL & BDL & $\mathrm{BDL}$ \\
\hline 2-Methyl-4,6-dinitrophenol & 0.5 & BDL & BDL & $\mathrm{BDL}$ \\
\hline Pentachlorophenol & 1 & BDL & BDL & BDL \\
\hline
\end{tabular}


Table 5. Concentration ranges of selected organics from TCLP experiments performed with synthetic CSG water.

\begin{tabular}{|c|c|c|c|c|}
\hline \multirow{2}{*}{$\begin{array}{c}\text { Polycyclic aromatic } \\
\text { hydrocarbons }\end{array}$} & \multirow{2}{*}{$\begin{array}{c}\text { Detection Limit } \\
(\mu \mathrm{g} / \mathrm{L})\end{array}$} & \multicolumn{3}{|c|}{ Coal Rank } \\
\hline & & Lignite & HvA-Bituminous & Mv-Bituminous \\
\hline Naphthalene & 0.01 & $0.58-0.64$ & BDL & $\mathrm{BDL}$ \\
\hline Acenaphthylene & 0.01 & $\mathrm{BDL}$ & BDL & $\mathrm{BDL}$ \\
\hline Acenaphthene & 0.01 & BDL & BDL & $\mathrm{BDL}$ \\
\hline Fluorene & 0.01 & BDL & BDL & $\mathrm{BDL}$ \\
\hline Phenanthrene & 0.01 & 0.01 & $\mathrm{BDL}$ & $\mathrm{BDL}$ \\
\hline Anthracene & 0.01 & BDL & BDL & BDL \\
\hline Fluoranthene & 0.01 & BDL & BDL & BDL \\
\hline Pyrene & 0.01 & BDL & BDL & BDL \\
\hline Benz[a]anthracene & 0.01 & BDL & BDL & BDL \\
\hline Chrysene & 0.01 & BDL & BDL & BDL \\
\hline Benzo $[\mathrm{b}+\mathrm{k}]$ fluoranthene & 0.01 & $\mathrm{BDL}$ & BDL & $\mathrm{BDL}$ \\
\hline Benzo[a]pyrene & 0.01 & BDL & BDL & BDL \\
\hline Indeno[1,2,3-cd]pyrene & 0.01 & BDL & BDL & $\mathrm{BDL}$ \\
\hline Dibenz[a,h]anthracene & 0.01 & BDL & BDL & BDL \\
\hline Benzo[ghi]perylene & 0.01 & $\mathrm{BDL}$ & $\mathrm{BDL}$ & $\mathrm{BDL}$ \\
\hline Phenolics & $\begin{array}{l}\text { Detection Limit } \\
(\mu \mathrm{g} / \mathrm{L})\end{array}$ & Lignite & HvA-Bituminous & Mv-Bituminous \\
\hline Phenol & 0.25 & $0.26-0.31$ & BDL & $\mathrm{BDL}$ \\
\hline 2-Chlorophenol & 0.25 & $\mathrm{BDL}$ & BDL & BDL \\
\hline 2-Methylphenol & 0.25 & $\mathrm{BDL}$ & BDL & BDL \\
\hline 4-Methylphenol & 0.25 & BDL & BDL & BDL \\
\hline 2-Nitrophenol & 0.25 & BDL & BDL & BDL \\
\hline 2,4-Dimethylphenol & 0.25 & BDL & BDL & BDL \\
\hline 2,4-Dichlorophenol & 0.25 & BDL & BDL & BDL \\
\hline 2,6-Dichlorophenol & 0.25 & BDL & BDL & BDL \\
\hline 4-Chloro-3-methylphenol & 0.25 & BDL & BDL & BDL \\
\hline 2,4,6-Trichlorophenol & 0.25 & BDL & BDL & $\mathrm{BDL}$ \\
\hline 2,4,5-Trichlorophenol & 0.25 & BDL & $\mathrm{BDL}$ & $\mathrm{BDL}$ \\
\hline 2,4-Dinitrophenol & 2.5 & BDL & BDL & BDL \\
\hline 4-Nitrophenol & 1 & $\mathrm{BDL}$ & BDL & $\mathrm{BDL}$ \\
\hline 2,3,4,6-Tetrachlorophenol & 0.3 & $\mathrm{BDL}$ & BDL & BDL \\
\hline 2-Methyl-4,6-dinitrophenol & 0.5 & BDL & BDL & BDL \\
\hline Pentachlorophenol & 1 & BDL & BDL & BDL \\
\hline
\end{tabular}

The bituminous coals leached individual PAH compounds with less consistency than the lignite sample. The HvA-bituminous sample leached PAH compounds in only two of the five TCLPs and only in deionized water. PAHs leached from the HvA-bituminous coal were pyrene $(0.01$ to $0.02 \mu \mathrm{g} / \mathrm{L})$ and fluoranthene (0.01 to $0.03 \mu \mathrm{g} / \mathrm{L}$ ) (Figure 2). The Mv-bituminous coal leached PAH compounds in three of the five TCLPs performed with that coal and only in deionized water, not to synthetic CSG water. The leachate of a powdered Mv-bituminous coal (in deionized water) contained similar PAHs as only one of the roughly crushed Mv-bituminous leachates. 
Figure 2. Aromatics (mostly PAHs) leached from coal samples with deionized water and their relative concentrations. PAHs reported from Walloons CSG water samples are also shown.

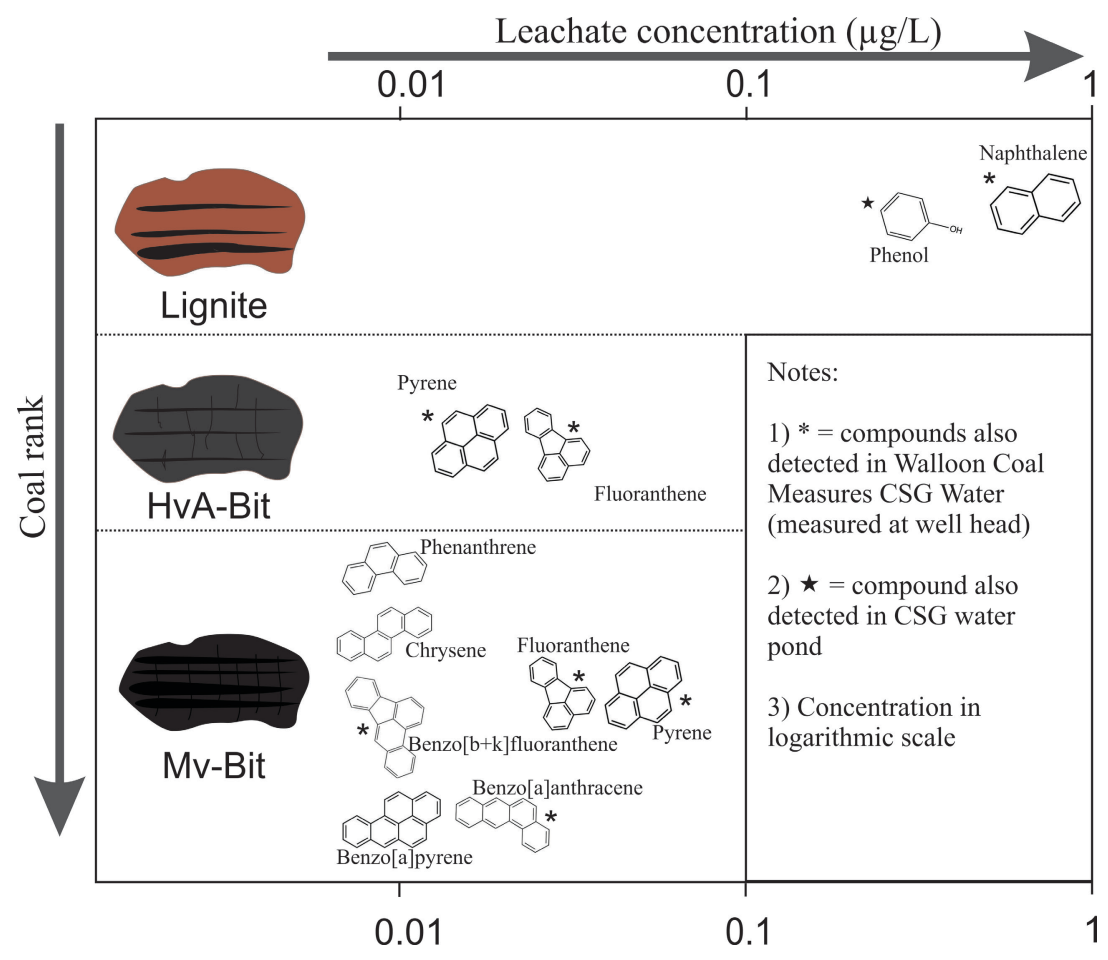

\section{CSG Water Discussion}

The PAH compounds identified in the Walloons CSG water are likely coal derived, based on their similarity to: known PAH composition in coals [43,44], PAHs leached from coals herein (Tables 4 and 5), and PAHs identified in CSG Water of the Powder River Basin [28]. Naphthalene and phenanthrene are the most water soluble PAHs, likely accounting for their increased presence in CSG waters relative to the higher molecular weight PAHs (see Table 6). However, the lower molecular weight PAHs detected in the Walloon Coal Measures CSG water (naphthalene, phenanthrene and pyrene) are considered to be less harmful to human health than the higher molecular weight PAHs [45]. The detected PAHs with 4 and 5 aromatic rings - chrysene, benzo[b]fluoranthene and dibenz[a]anthracene — are suspected human carcinogens $[45,46]$, based largely on data from toxicological tests in rodents. The higher molecular weight PAHs, such as benzo[a]pyrene and dibenzo[a,1]pyrene (5 and 6 rings, respectively), are suggested to cause cancer through metabolic activation in cells and formation of stable adducts that damage DNA [47-49]. Benzo[a]pyrene $(\mathrm{BaP})$ is the only PAH with a trigger threshold $(0.01 \mu \mathrm{g} / \mathrm{L})$ in Australian drinking water guidelines (ADWG). The ADWG state that insufficient data are available to set a guideline limit for other PAHs (National Health and Medical Research Council, Canberra, ACT, Australia, 2004). Orem et al. [28] summarized international PAH guidelines in drinking water according to the United States Environmental Protection Agency (USEPA) and World Health Organization (WHO). Under the ADWG, USEPA and WHO guidelines, no single Walloon CSG well produced water that would exceed the regulatory levels for PAHs. The drinking water guidelines are provided purely as a relative index to the aromatic concentrations in CSG water and do not imply that untreated CSG water is ever used as potable supply in Queensland. Under Australian environmental guidelines [50], such as those applied to water quality in aquatic ecosystems, only naphthalene has a 
trigger value (16 $\mu \mathrm{g} / \mathrm{L}$ for a $95 \%$ species protection level) whereas all higher molecular weight PAHs have insufficient data available to set guideline values.

None of the higher molecular weight, potentially harmful PAHs present at very low concentrations in the CSG water from Walloon wells were present in the holding pond. This is an important consideration when reviewing CSG water quality data from production wells, particularly in the context of ultra-trace organics and also because the holding pond is the feedstock for treatment and beneficial reuse of CSG water. If a small number of wells produce CSG water containing minute amounts of suspected harmful PAHs and the vast majority of wells do not produce CSG water with those compounds above the detection limit, then the PAHs may be further diluted by mixing in the holding ponds. Therefore analysis - particularly of the very insoluble PAH compounds discussed here-may result in nil detection of those compounds from the ponds, despite their presence in water from individual wells. Other processes, such as rainwater input, the binding of PAHs to soils and sediments [51] and UV degradation [52,53] may also reduce PAH concentrations in ponded water.

Orem et al. [28] identified PAHs including naphthalene, phenanthrene, fluorene and pyrene in CSG water from a small number of wells targeting the Powder River Basin coals. However, that work more commonly identified functional derivatives of $\mathrm{PAH}$ compounds (e.g., alkylated naphthalene, methylpyrene, dimethylphenanthrene) that are not regular water quality analytes in Queensland and often have unknown toxicities. Derivative forms of PAHs are a significant part of the molecular composition of coals [54] and necessitate higher resolution analysis of QLD CSG water to quantify their occurrence and any potential health risks those compounds may pose.

\subsection{Leaching Experiment Discussion}

The concentrations of organics leached from lignite were an order of magnitude greater than the bituminous samples (Figure 2). This concurs with the increased solubilization of lower rank coals relative to higher rank coals as described by some authors [27,55]. In aqueous leaching experiments of various coals, Maharaj et al. [56] also observed higher concentrations of aromatics in some (but not all) lignite leachates relative to bituminous samples. Naphthalene and phenol are more soluble than the higher molecular weight PAHs (Table 6 [57,58]) and also more likely to be cleaved from the less condensed aromatic framework of a low rank coal [55]. This is consistent with the increased presence and concentration of lower molecular weight PAHs (and their derivatives) in organic results from CSG wells targeting lignite to sub-bituminous coals of the Powder River Basin [28].

PAHs detected in Mv-bituminous leachate were of 3, 4 and 5 aromatic ring structures, including pyrene, fluoranthene, chrysene, benzo[a]anthracene, benzo[b+k]fluoranthene and benzo[a]pyrene. Benzo[a]pyrene $(\mathrm{BaP})$ is a known carcinogen with very low solubility and high affinity to remain in the organic phase [59,60]. It is detected in the Mv-bituminous leachate results at its threshold concentration in the ADWG $(0.01 \mu \mathrm{g} / \mathrm{L})$. The filtered coal leachates likely contained other dissolved humic material from the coals given the observed yellow/brown colour. The presence of this organic matter may have enhanced the solubility of $\mathrm{BaP}$ and other higher molecular weight PAHs [61]. 
Table 6. Aromatic compounds detected in Walloon Coal Measures CSG water and leaching experiments with their physico-chemical properties [57,58].

\begin{tabular}{ccccc}
\hline Compound & $\begin{array}{c}\text { Molar Mass } \\
(\mathbf{g} / \mathbf{m o l})\end{array}$ & $\begin{array}{c}\text { Solubility at } \\
\mathbf{2 5} \mathbf{~}^{\circ} \mathbf{C}(\boldsymbol{\mu g} / \mathbf{L})\end{array}$ & Log KoW * & $\begin{array}{c}\text { No. of } \\
\text { Aromatic Rings }\end{array}$ \\
\hline Phenol & 94.1 & $83,000,000$ & 1.46 & 1 \\
Naphthalene & 128.2 & 31,000 & 3.37 & 2 \\
Phenanthrene & 178.2 & 465 & 4.46 & 3 \\
Fluoranthene & 202.3 & 260 & 4.9 & 3 \\
Pyrene & 202.1 & 133 & 4.88 & 4 \\
Benz[a]anthracene & 228.3 & 11 & 5.63 & 4 \\
Chrysene & 228.3 & 1.9 & 5.63 & 4 \\
Benzo[b]fluoranthene & 252.3 & 2.4 & 6.04 & 4 \\
Benzo[k]fluoranthene & 252.3 & 2.4 & 6.21 & 4 \\
Benzo[a]pyrene & 252.3 & 3.8 & 6.06 & 5 \\
Dibenz[a]anthracene & 278.3 & 0.4 & 6.86 & 5 \\
\hline
\end{tabular}

Note: * Log Kow refers to the octanol-water partition coefficient whereby higher values denote compounds more likely to partition into organic phases rather than aqueous phases.

The 3-5 ring PAHs present in the deionized water leachates of bituminous coals were not detected in the synthetic CSG water leachates. PAHs leached in deionized water were exceedingly low and their absence in the synthetic CSG water may relate to the decreased ability of that fluid to leach and dissolve very non-polar substances as ionic strength increases [62,63]. The lack of phenol in the bituminous leachates may relate to their increased coal maturity. As coalification increases (and $\mathrm{O}$ and $\mathrm{H}$ decrease) the concentrations of hydroxylated aromatics are lowered relative to those present in lower rank coals [44].

\subsection{Aromatic Compound Mobilization from Coal}

The macromolecular network of coal contains aromatics in two phases. During coalification, resistant plant biopolymers are turned into a progressively denser, aromatic, three-dimensional network [42]. Within the network structure, a "mobile" phase of smaller molecules is more weakly bonded and can more easily leach to the environment [64]. The mobility of these compounds makes them of greater human health concern. The PAHs present in the leachates of coal samples most likely represent constituents of the mobile phase.

The leach results suggest that types of compounds leached from coals to deionized water become increasingly aromatic with increasing coal rank. The lowest rank coal leached 1 and 2 ring aromatics at the highest concentrations and the highest rank coal leached 3, 4 and 5 ring aromatics at the lowest concentrations (Figure 2). Conversely, Stout et al. [43] observed more 4-6 ring PAHs in extracts of lignite and sub-bituminous coals compared with greater 2-3 ring PAHs in higher rank coals of the western United States. In addition, those authors showed an increasing concentration of total PAHs in coal with coalification (up to the bituminous rank) (see Figure 4 of [43]). However, the types of aromatics in the molecular structure of coal do not have a systematic relationship to coal maturity alone. Detailed maceral composition (currently unavailable for these samples) and coal origin is also a 
major factor [44,54]. Laumann et al. [54] observed that when considering coals of different origin from multiple basins, 2-3 ring PAHs dominate molecular composition regardless of coal maturity.

Results from previous studies $[43,54]$ in which compounds were extracted with organic solvent are not directly comparable to this study, however. Extract composition from natural water will likely differ depending on PAH sorb/desorb behaviour, the ability of coal to act as a geosorbent, PAH solubility in natural waters and the co-elution of PAHs to other dissolved humic material. For example, the very low concentrations of the higher molecular weight (and potentially harmful) 3-5 PAHs detected in the bituminous leachates may be better explained by their very low solubilities in water and higher binding affinities (Log Kow) for organic matter (Table 6), rather than their relative abundances in coal samples.

Attempting to predict types and concentrations of leached aromatic compounds based purely on coal properties of individual seams may prove unrealistic when trying to correlate these results to the concentration of compounds in water samples from actual CSG production fields. Complications in such modelling would arise when sampling water from open-hole completed wells, where many potentially variable coal seams and their inter-seam sediments are targeted for gas extraction. Also, the inflow of groundwater from aquifers hydraulically connected to the coal seams may dilute any expected compounds, thus site specific hydrogeological conditions must be considered. Where hydraulic fracturing has occurred, organic additives used in injection fluids (see Table 2 of [3]) may also have the potential to solubilize coal derived hydrocarbons [29] to CSG waters, particularly where flowback recovery does not appropriately "flush" the formation water. Furthermore, some insoluble aromatic compounds reported in this study occur very close to their detection limits and thus their analytical reproducibility in CSG water may be infrequent.

\subsection{Human Health Risk}

The first phase of human health risk assessment includes hazard identification and dose response. That is, identification of a substance or situation that has the potential to cause adverse health effects and at what levels of exposure (dose). Risk, as a measure of likelihood of occurrence and severity of outcome, is usually then assessed based on site-specific characterization of pathways of human exposure including acute, cumulative and multiple exposures. Additionally, physiological response to dose may predict the severity of human response or adverse health effects.

This study provides evidence that a minority of Queensland CSG water samples contain some organic compounds recognized as potential health hazards. The significance of these findings however, lies in the relatively small number of samples containing the compounds and the very low concentrations in which they are present. These factors greatly reduce the likelihood of human exposure at doses significant to induce adverse physiological response, at least in short-term exposure scenarios. If present, many potentially harmful coal derived substances can be reduced to negligible levels with common CSG water treatment methods [4,26,31]. Yet more publicly available research employing low detection level $(<1 \mu \mathrm{g} / \mathrm{L})$ analysis of the wide range of potentially dissolved organics in CSG water would assist in refining risk assessments and site-specific treatment methods.

The risk is less clear for hazard accumulation and multiple exposure scenarios and this uncertainty indicates the need for further analysis of both models of organic compound accumulation and migration 
in ground and surface water before and after treatment and definition of potential pathways of human exposure to these waters. Additionally, future toxicology studies targeting the key compounds identified in this study can clarify the dose-response relationship to adverse health outcomes. A broader understanding of these issues will provide the basis for informed and appropriate industry regulation to best monitor for and militate against release of hazardous substances through CSG production.

\subsection{Detection Limits and Reporting}

In some instances, the detection level (DL) of some organic compound classes in CSG water may be too high to adequately assess the occurrence of potentially harmful compounds. Aromatic compounds such as BaP have regulatory limits $(0.01 \mu \mathrm{g} / \mathrm{L}) 50$ times less concentrated than the minimum DL of the Bandanna Formation dataset $(0.5 \mu \mathrm{g} / \mathrm{L})$ of this work and the small number of publicly available QLD CSG water organic datasets. Analysis at this level prevented a comparison of dissolved aromatics from Walloon and Bandanna production fields. In addition, relatively high DLs still leave a knowledge gap regarding the occurrence of generally insoluble, but environmentally regulated coal derived organics. $\mathrm{BaP}$ was leached from coal in this study at its regulatory limit, thus highlighting the importance of appropriate DLs in CSG water analysis.

Sometimes (even where DLs are sufficiently low) average concentrations of organic compounds across production fields are reported rather than ranges of detected levels. Whilst such reporting is practical for characterizing CSG water quality for legislative requirements and bulk treatment technologies, rare relatively high concentrations of organic compounds detected from individual wells may be ameliorated by the field average. It is therefore best practice to present organic concentrations of CSG water from individual wells in monitoring and regulatory data, as well as production field averages.

\section{Conclusions}

Analyses conducted in this study show that BTEX compounds and phenolic compounds were absent from CSG waters in the Bandanna Formation (Bowen Basin) and Walloon Coal Measures (Surat Basin) from production wells operating between 2009 and 2010. Coal seam gas water in the Surat Basin can contain ultra-trace ranges of polycyclic aromatic hydrocarbons (PAHs) including: naphthalene, phenanthrene, chrysene, benzo[b]fluoranthene and dibenz[a]anthracene, which are most likely sourced from the sub-bituminous to bituminous coals of the Walloon Coal Measures. Some of these compounds are suspected toxins. However, no single producing well contained organic compounds in concentrations that would exceed Australian Drinking Water Guidelines, or USEPA and WHO drinking water guidelines for PAHs. In addition, the holding pond for the Walloons production area contained none of the 3-5 ring PAHs detected in water samples from the CSG wells.

One aim of this study was to assess the potential differences between structure and concentration of organics leached from different ranked coals. However, coal leaching results could not be compared directly to CSG water sample analyses which had been previously collected by CSG producers, because of the higher detection limits associated with these sample analyses (e.g., detections $\geq 1 \mu \mathrm{g} / \mathrm{L}$ for the Bandanna Formation CSG water). An analysis with a minimum detection level circa $0.01 \mu \mathrm{g} / \mathrm{L}$ is more in line with trigger levels for regulated compounds such as benzo[a]pyrene, a known 
carcinogen which was shown to leach from a bituminous coal in a laboratory setting. Should CSG operators have approval for untreated beneficial use of CSG water (e.g., discharge to streams, land irrigation, managed aquifer injection), it is recommended that the $\mathrm{BaP}$ limits of detection used in $\mathrm{PAH}$ analysis should be set at $0.01 \mu \mathrm{g} / \mathrm{L}$ (the most stringent regulatory level).

PAHs are present within coal samples at appreciable concentrations [44,54], but only ultra-trace concentrations of the more toxic higher molecular weight PAHs are likely to leach to waters because they are hydrophobic organic substances. Variable aromatic structures (PAHs and phenols) will likely leach from coals of different rank. Higher molecular weight PAH compounds were leached to water (including chrysene, benzo[a]anthracene and benzo[a]pyrene) from the highest rank coal analyzed in this study, whilst lower molecular weight compounds leached at greater concentrations from the lowest coal rank. This trend seems to correlate with conceptual trend of increasing aromaticity of the coal molecular structure with increasing rank, but maceral composition and the presence of other dissolved organic material could be playing a role in which water soluble PAHs are present in leachates. None of the 4 and 5 ringed PAHs leached to the more saline synthetic CSG water, and this may indicate that brackish to saline CSG waters further reduce the solubilities of very hydrophobic organic toxins. Further work with a range of controlled leaching experiments would be required to fully understand this process. Additional experimental work is recommended to assess the potential of organic additives, present in hydraulic fracturing fluids, to mobilize hydrocarbons from coal to flowback water (and to assess potential CSG water contamination by flowback water).

Coal is a heterogeneous material and each coal seam gas field may present a unique inventory of organic compounds needing characterization and assessment to fully understand coal-groundwater interactions and ultimately water quality. Moreover, there is potentially a far wider range of organic compounds mobilized from coals to CSG water beyond the common environmental analytes of this study, including heterocyclic compounds, biphenyls, aromatic amines and non-aromatic compounds.

The high density of CSG wells in southern Queensland provides an excellent opportunity to better understand the relationship between coal and groundwater. In turn, such studies form the basis of human health risk assessment and may be significant in understanding the etiology of disease linked to coal-derived organic compounds such as Balkan Endemic Nephropathy. Moreover, communities that access untreated groundwater from coal-associated aquifers (e.g., Powder River Basin, WY and Surat Basin, QLD) can use such studies to gain a better understanding of the potential risks posed by water soluble coal-derived organics.

Improved stakeholder confidence in CSG operations and water issues will only result from access to appropriate, peer reviewed research, to which this study may contribute. Finally, CSG water characterization studies are crucial in developing industry best practice, as well as government regulation, monitoring and management strategies for CSG water to safeguard the environment and human health in parallel with expanding CSG production.

\section{Acknowledgments}

We thank Greg Jackson, Aaron Hieatt and Janet Cummings (Water Team, Department of Health, QLD Government, Brisbane, QLD, Australia), for their assistance in data collation and setup for experimental and analytical work. Stewart Carswell and Benjamin Tan of Queensland Health Forensic 
and Scientific Services (QHFSS) provided laboratory space and analytical support and Australian Laboratory Services (ALS), Brisbane provided analytical advice.

\section{Author Contributions}

William Stearman: Collated, reviewed and analysed government CSG water quality data and performed experimental work and analytical extractions for leaching tests; primary author on paper, contributed to figures and editing. Mauricio Taulis: Project supervision; contributed to experimental design; wrote sections of the paper; reviewed and edited drafts of paper; drafted and edited figures. Maree Corkeron: Project supervision; contributed to project design; sourced relevant desktop data; wrote sections of the paper; reviewed and edited drafts of paper. James Smith: Assisted with organic geochemical concepts and experimental design; reviewed and edited drafts.

\section{Conflicts of Interest}

The authors declare no conflict of interest.

\section{References}

1. Blueprint for Queensland's LNG Industry, LNG Industry Unit. Available online: http://rti.cabinet.qld.gov.au/documents/2010/nov/lng\%20blueprint/Attachments/LNG\%20Bluepri nt.pdf (accessed on 1 September 2014).

2. Klohn Crippen Berger. Forecasting Coal Seam Gas Water Production in Queensland's Surat and Southern Bowen Basins; Department of Natural Resources and Mines: Brisbane, Australia, 2012.

3. Sinclair Knight Mertz. Hydraulic Fracturing Techniques ("Fraccing”) Techniques, including Reporting Requirements and Governance Arrangements, Background Review; Commonwealth of Australia: Canberra, Australia, 2014.

4. National Research Council. Management and Effects of Coalbed Methane Produced Water in the United States; National Academy of Sciences: Washington, DC, USA, 2010.

5. Batley, G.E.; Kookana, R.S. Environmental issues associated with coal seam gas recovery: Managing the fracking boom. Environ. Chem. 2012, 9, 425-428.

6. Taulis, M.E. Australia and New Zealand CBNG development and environmental implications. In Coalbed Natural Gas: Energy and Environment; Reddy, K.J., Ed.; Nova Science Publishers: New York, NY, USA, 2010; pp. 401-424.

7. Taulis, M.E. Groundwater Characterisation and Disposal Modelling for Coal Seam Gas Recovery; University of Canterbury: Christchurch, New Zealand, 2007.

8. Department of Environment and Heritage Protection. Coal Seam Gas Water Management Policy; QLD Government: Brisbane, Australia, 2012.

9. Dr Mariann Lloyd-Smith Speaking about Toxic Risks of CSG (aka Coal Bed Methane). Available online: http://www.faug.org.uk/link/dr-mariann-lloyd-smith-speaking-about-toxic-risks-csg-akacoal-bed-methane (accessed on 18 June 2014).

10. Feder, G.L.; Radovanovic, Z.; Finkelman, R.B. Relationship between weathered coal deposits and the etiology of Balkan endemic nephropathy. Kidney Int. Suppl. 1991, 34, 9-11. 
11. Tatu, C.A.; Orem, W.H.; Maharaj, S.V.M.; Finkelman, R.B.; Diaconita, D.; Feder, G.L.; Szilagyi, D.N.; Dumitrascu, V.; Paunescu, V. Organic compounds derived from Pliocene lignite and the etiology of Balkan endemic nephropathy. In Geology and Health: Closing the Gap; Skinner, H.C.W., Berger, A.R., Eds.; Oxford University Press: New York, NY, USA, 2003; pp. 159-162.

12. Orem, W.; Tatu, C.; Pavlovic, N.; Bunnell, J.; Lerch, H.; Paunescu, V.; Ordodi, V.; Flores, D.; Corum, M.; Bates, A. Health effects of toxic organic substances from coal: Toward "Panendemic" nephropathy. AMBIO 2007, 36, 98-102.

13. Orem, W.H.; Feder, G.L.; Finkelman, R.B. A possible link between Balkan endemic nephropathy and the leaching of toxic organic compounds from Pliocene lignite by groundwater: Preliminary investigation. Int. J. Coal Geol. 1999, 40, 237-252.

14. Sunwater Ltd. Chinchilla Beneficial Use Scheme Water Quality Report; Sunwater Ltd.: Brisbane, Australia, 2013. Available online: http://www.sunwater.com.au/_data/assets/pdf_file/0016/12607/ Chinchilla-Beneficial-Use-Scheme-Water-Quality-Report-2013.pdf (accessed on 1 September 2014).

15. Navi, M.; Skelly, C.; Taulis, M.; Nasiri, S. Coal seam gas water: Potential hazards and exposure pathways in Queensland. Int. J. Environ. Health Res. 2014, 24, 1-22.

16. Cheung, K.; Sanei, H.; Klassen, P.; Mayer, B.; Goodarzi, F. Produced fluids and shallow groundwater in coalbed methane $(\mathrm{CBM})$ producing regions of Alberta, Canada: Trace element and rare earth element geochemistry. Int. J. Coal Geol. 2009, 77, 338-349.

17. Jackson, R.E.; Reddy, K.J. Geochemistry of coalbed natural gas (CBNG) produced water in powder river basin, wyoming: Salinity and sodicity. Water Air Soil Pollut. 2007, 184, 49-61.

18. Jackson, R.E.; Reddy, K.J. Trace element chemistry of coal bed natural gas produced water in the Powder River Basin, Wyoming. Environ. Sci. Technol. 2007, 41, 5953-5959.

19. Jackson, R.E.; Reddy, K.J. Coalbed natural gas product water: Geochemical transformations from outfalls to disposal ponds. In Coalbed Natural Gas: Energy and Environment; Reddy, K.J., Ed.; Nova Science Publishers Inc.: New York, NY, USA, 2010; pp. 121-143.

20. Kinnon, E.C.P.; Golding, S.D.; Boreham, C.J.; Baublys, K.A.; Esterle, J.S. Stable isotope and water quality analysis of coal bed methane production waters and gases from the Bowen Basin, Australia. Int. J. Coal Geol. 2010, 82, 219-231.

21. McBeth, I.; Reddy, K.J.; Skinner, Q.D. Chemistry of trace elements in coalbed methane product water. Water Res. 2003, 37, 884-890.

22. Patz, M.J.; Reddy, K.J.; Skinner, Q.D. Chemistry of coalbed methane discharge water interacting with semi-arid ephemeral stream channels. J. Am. Water Resour. Assoc. 2004, 40, 1247-1255.

23. Taulis, M.E.; Trumm, D.; Milke, M.W.; Nobes, D.; Manhire, D.; O’Sullivan, A. Characterisation of coal seam gas waters in New Zealand. In Proceedings of the New Zealand Minerals Conference: Realising New Zealand's Mineral Potential, Auckland, New Zealand, 13-16 November 2005; pp. 416-425.

24. Taulis, M.; Milke, M. Chemical variability of groundwater samples collected from a Coal Seam Gas exploration well, Maramarua, New Zealand. Water Res. 2012, 47, 1021-1034.

25. Reddy, K.J.; Helmericks, C.; Whitman, A.; Legg, D. Geochemical processes controlling trace elemental mobility in coalbed natural gas (CBNG) disposal ponds in the Powder River Basin, WY. Int. J. Coal Geol. 2014, 126, 120-127. 
26. Dahm, K.G.; Guerra, K.L.; Xu, P.; Drewes, J.E. Composite geochemical database for coalbed methane produced water quality in the Rocky Mountain region. Environ. Sci. Technol. 2011, 45, $7655-7663$.

27. Volk, H.; Pinetown, K.; Johnston, C.; McLean, W. A Desktop Study of the Occurrence of Total Petroleum Hydrocarbon (TPH) and Partially Water-Soluble Organic Compounds in Permian Coals and Associated Coal Seam Groundwater; CSIRO: Sydney, Australia, 2011.

28. Orem, W.H.; Tatu, C.A.; Lerch, H.E.; Rice, C.A.; Bartos, T.T.; Bates, A.L.; Tewalt, S.; Corum, M.D. Organic compounds in produced waters from coalbed natural gas wells in the Powder River basin, Wyoming, USA. Appl. Geochem. 2007, 22, 2240-2256.

29. Orem, W.; Tatu, C.; Varonka, M.; Lerch, H.; Bates, A.; Engle, M.; Crosby, L.; McIntosh, J. Organic substances in produced and formation water from unconventional natural gas extraction in coal and shale. Int. J. Coal Geol. 2014, 126, 20-31.

30. APLNG. Coal Seam Gas Water Quality Monitoring Program: Talinga Water Treatment Facility. Available online:http://www.aplng.com.au/pdf/water_monitoring_management/Appendix_JCSG_Water_Quality_Monitoring_Program_Talinga_Water_Treatment_Facility.pdf (accessed on 1 September 2014).

31. Arrow Energy Ltd. Coal Seam Gas Water Management Plan. Surat Basin; Doc No. ENV11-133; Arrow Energy Ltd.: Brisbane, Australia, 2013.

32. Sowder, J.T.; Kelleners, T.J.; Reddy, K.J. The origin and fate of arsenic in coalbed natural gas-produced water ponds. J. Environ. Qual. 2010, 39, 1604-1615.

33. Beeston, J.W. Coal facies depositional models, Denison trough area, Bowen Basin. Qld. Geol. 1991, 2, 3-33.

34. Beeston, J.W. Coal rank variation in the Bowen Basin, Queensland. Int. J. Coal Geol. 1986, 6, 163-179.

35. Draper, J.J.; Boreham, C.J. Geological controls on exploitable coal seam gas distribution in Queensland. Aust. Pet. Prod. Explor. Assoc. J. 2006, 46, 343-346.

36. Salehy, M.R. Determination of rank and petrographic composition of Jurassic coals from eastern Surat Basin, Australia. Int. J. Coal Geol. 1986, 6, 149-162.

37. Fielding, C.R. The middle Jurassic Walloon coal measures in the type area, the Rosewood-Walloon Coalfield, SE Queensland. Aust. Coal Geol. 1993, 9, 4-16.

38. Scott, S.; Anderson, B.; Crosdale, P.; Dingwall, J.; Leblang, G. Coal petrology and coal seam gas contents of the Walloon Subgroup-Surat Basin, Queensland, Australia. Int. J. Coal Geol. 2007, 70, 209-222.

39. Exon, N.F. Geology of the Surat Basin in Queensland; Bulletin 166; Bureau of Mineral Resources, Geology and Geophysics: Canberra, Australia, 1976.

40. Clark, W.J.; Cooper, D.M. Sedimentological and wireline aspects of the Walloon Coal Measures in GSQ Dalby 1 and GSQ Chinchilla 3, Surat Basin, Queensland. Qld. Govt. Min. J. 1985, 86, 386-394.

41. Radke, M.; Willsch, H.; Leythaeuser, D.; Teichmüller, M. Aromatic components of coal: Relation of distribution pattern to rank. Geochim. Cosmochim. Acta 1982, 46, 1831-1848.

42. Hatcher, P.G.; Clifford, D.J. The organic geochemistry of coal: From plant materials to coal. Org. Geochem. 1997, 27, 251-274. 
43. Stout, S.A.; Emsbo-Mattingly, S.D. Concentration and character of PAHs and other hydrocarbons in coals of varying rank-Implications for environmental studies of soils and sediments containing particulate coal. Org. Geochem. 2008, 39, 801-819.

44. Achten, C.; Hofmann, T. Native polycyclic aromatic hydrocarbons (PAH) in coals-A hardly recognized source of environmental contamination. Sci. Total Environ. 2009, 407, 2461-2473.

45. Agency for Toxic Substances and Disease Registry. Toxicological Profile for Polycyclic Aromatic Hydrocarbons; Public Health Service: Atlanta, GA, USA, 1995.

46. Luch, A.; Baird, W.M. Carcinogenic Polycyclic Aromatic Hydrocarbons. In Comprehensive Toxicology; Charlene, A.M., Ed.; Elsevier: Oxford, UK, 2010; pp. 85-123.

47. Melendez-Colon, V.J.; Luch, A.; Seidel, A.; Baird, W.M. Cancer initiation by polycyclic aromatic hydrocarbons results from formation of stable DNA adducts rather than apurinic sites. Carcinogenesis 1999, 20, 1885-1891.

48. Luch, A.; Baird, W.M. Metabolic Activation and Detoxification of Polycyclic Aromatic Hydrocarbons; Imperial College Press: London, UK, 2004.

49. Xue, W.; Warshawsky, D. Metabolic activation of polycyclic and heterocyclic aromatic hydrocarbons and DNA damage: A review. Toxicol. Appl. Pharmacol. 2005, 206, 73-93.

50. Australian and New Zealand Environment and Conservation Council. Australian Water Quality Guidelines for Fresh and Marine Water Quality; ANZECC: Kingston, UK, 2000; Volume 1.

51. Jafvert, C.T.; Rao, P.S.C.; Lane, D.; Lee, L.S. Partitioning of mono- and polycyclic aromatic hydrocarbons in a river sediment adjacent to a former manufactured gas plant site. Chemosphere 2006, 62, 315-321.

52. Bertilsson, S.; Widenfalk, A. Photochemical degradation of PAHs in freshwaters and their impact on bacterial growth - Influence of water chemistry. Hydrobiologia 2002, 469, 23-32.

53. Sabaté, J.; Bayona, J.M.; Solanas, A.M. Photolysis of PAHs in aqueous phase by UV irradiation. Chemosphere 2001, 44, 119-124.

54. Laumann, S.; Micić, V.; Kruge, M.A.; Achten, C.; Sachsenhofer, R.F.; Schwarzbauer, J.; Hofmann, T. Variations in concentrations and compositions of polycyclic aromatic hydrocarbons (PAHs) in coals related to the coal rank and origin. Environ. Pollut. 2011, 159, 2690-2697.

55. Santamaria, A.B.; Fisher, J. Dissolved organic constituents in coal associated waters, and implications for human and ecosystem health. Toxicol. Sci. 2003, 72, 396-397.

56. Maharaj, S.V.M.; Orem, W.H.; Tatu, C.A.; Lerch, H.E., III; Szilagyi, D.N. Organic compounds in water extracts of coal: Links to Balkan endemic nephropathy. Environ. Geochem. Health 2014, $36,1-17$.

57. Neff, J.M. Polycyclic Aromatic Hydrocarbons in the Aquatic Environment; Applied Science Publishing Ltd.: London, UK, 1979.

58. United States Environmental Protection Agency. Ambient Water Quality Criteria for Polynuclear Aromatic Hydrocarbons; EPA: Washington, WA, USA, 1980.

59. De Maagd, P.G.-J.; Hulscher, T.D.; van den Heuvel, T.; Opperhuizen, A.; Sijm, D.T.H.M. Physicochemical properties of polycyclic aromatic hydrocarbons: Aqueous solubilities, $n$-octanol/water partition coefficients, and Henry's Law constants. Environ. Toxicol. Chem. 1998, 17, 251-257. 
60. Hegeman, W.J.M.; van der Weijden, C.H.; Loch, J.P. Sorption of benzo[a]pyrene and phenanthrene on suspended harbor sediment as a function of suspended sediment concentration and salinity: A laboratory study using the cosolvent partition coefficient. Environ. Sci. Technol. 1995, 29, 363-371.

61. Maxin, C.R.; Kogel-Knabner, I. Partitioning of polycyclic aromatic hydrocarbons (PAH) to water-soluble soil organic matter. Eur. J. Soil Sci. 1995, 46, 193-204.

62. Fu, G.; Kan, A.T.; Tomson, M. Adsorption and desorption hysteresis of PAHs in surface sediment. Environ. Toxicol. Chem. 1994, 13, 1559-1567.

63. Kan, A.T.; Fu, G.; Tomson, M.B. Adsorption/desorption hysteresis in organic pollutant and soil/sediment interaction. Environ. Sci. Technol. 1994, 28, 859-867.

64. Given, P.H. The Mobile Phase in Coals: Its Nature and Modes of Release; U.S. Department of Energy: Washington, DC, USA, 1987.

(C) 2014 by the authors; licensee MDPI, Basel, Switzerland. This article is an open access article distributed under the terms and conditions of the Creative Commons Attribution license (http://creativecommons.org/licenses/by/3.0/). 